\title{
Failure and failing, an ethos of the (self) exiled? The case of the playwright William Saroyan
}

\section{Charikleia Magdalini Kefalidou}

\section{(2) OpenEdition \\ Journals}

\section{Electronic version}

URL: https://journals.openedition.org/agon/8325

DOI: 10.4000/agon.8325

ISSN: 1961-8581

\section{Publisher}

Association Agôn

\section{Electronic reference}

Charikleia Magdalini Kefalidou, "Failure and failing, an ethos of the (self) exiled? The case of the playwright William Saroyan", Agôn [Online], 9 | 2021, Online since 25 September 2021, connection on 23 January 2022. URL: http://journals.openedition.org/agon/8325 ; DOl: https://doi.org/10.4000/agon. 8325

This text was automatically generated on 23 January 2022.

Association Agôn et les auteurs des articles 


\title{
Failure and failing, an ethos of the (self) exiled? The case of the playwright William Saroyan
}

\author{
Charikleia Magdalini Kefalidou
}

\section{AUTHOR'S NOTE}

The author would like to thank Forever Saroyan LLC, for their precious help.

I play not marches for accepted victors only, I play marches for conquer'd and slain persons. Have you heard that it was good to gain the day? I also say it is good to fall, battles are lost in the same spirit in which they are won. [...]

Vivas to those who have fail'd!

And to those whose war-vessels sank in the sea! And to those themselves who sank in the sea!

Walt Whitman

You might even say I was successful in spite of the fact I have always failed. I have always written what I had to write, such as this. [...] It hasn't got a plot, and there aren't any big parts in it for any of the stars of stage or screen. For all I know, it doesn't have a chance of being published, even ${ }^{2}$. William Saroyan

Born into a family of immigrants in the Armenian quarter of Fresno, California and fatherless by the age of three, William Saroyan (1908-1981) had a rather rough upbringing. Having spent his early years in an orphanage and growing up amongst poor families of immigrant stock, Saroyan could not possibly relate to the privileged 
milieu of the French and British novelists he used to read as a child at Fresno Public Library: « My world was a world of plain poor people, broken-down houses, casualness, good health, poverty and uproarious laughter rather than the world of complex and wealthy people, cultivated ease [and] discreet laughter ${ }^{3} »$. Early in his life, Saroyan experienced at first hand the hostility and prejudice against Armenians by the locals in Fresno coupled with the loss of his father, which he would later on describe as an upbringing marred by the failure of the protector of the family: « My father, Armenak of Bitlis [...] the failed poet, the failed Presbyterian preacher, the failed American, the failed theological student ${ }^{4} »$.

2 Saroyan was very well aware of his outsider status in life, which played a decisive role for his future career. Drawing from his experience as an unwanted immigrant and an exiled person, Saroyan developed an ethos of an eccentric individual and writer, a term

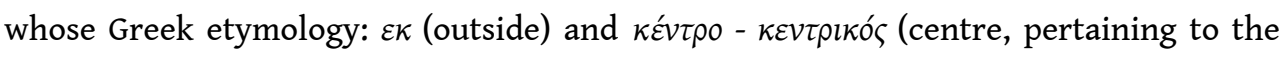
centre), someone whose attitudes and beliefs are placed far from the norm i.e., the " centre ", bears close resemblance to the definition of the exiled individual as a " decentred ${ }^{5}$ » being. His eccentric views and posture compliment his geographical and social exile and are channelled through his writing, which consciously and systematically defies norms and expectations about core elements of the American society such as materialism, capitalism and liberalism, as well as deconstructs the American Dream and criticises the American society's obsession with control, success and efficiency.

3 Saroyan delved precisely into his immigrant experience and developed a counterhegemonical stance defined as « a discourse [that challenges] dominant assumptions, beliefs and established patterns of behavior ${ }^{6}$ ", as a response to the commodification of art by the capitalist system. His narratives of unapologetic outsiderhood trivialising failure and voicing pride in otherness allow us to view failure under a new light: not as punishment for not conforming to the society's standards but as a way out of hegemonic dipoles and as proof of the humanity's connection with their inner child that is still untouched by the society's expectations, portrayed by the figure of the dreamer in Saroyan's work. Saroyan's dreamers are in fact avatars of the writer and artists themselves, reflecting their ambivalent status and their positioning in-between social fields; between the artistic and literary field characterised by the need of liberty and unconventionality as non-negotiable conditions for the expression of creativity, and the social field, whose pragmaticism is often in conflict or incompatible with the artist's identity and scopes. In order to grasp the unconventional ways that artists and writers such as Saroyan are sometimes inclined to deal with conventional perceptions of success and failure, we will delve into the specificities of the writers' and artists' social positioning, which can be described as in-betweenness or as a form of creative exile.

\section{Paratopic positioning: interpreting the writer's exile and ambivalent status}

Due to their inseparability from the core notions of creation and inspiration, literary writing and artistic activities are often considered incompatible with standard practices of the market and the workplace, which are more or less strictly regulated by a certain mode of exercise and require proof of productivity and profitability. 
According to the sociologist of art Nathalie Heinich, creative activities bear the characteristics of a calling or a mission, which render the professional status of writers almost impossible to determine without resorting to compromise or injustice towards the creators ${ }^{7}$.

Writing stems from the writer's desire to express themselves in a creative way, rather than from a real demand of the market for the works produced, especially in the context of utilitarian societies. Following the publication of a piece of writing, the work might yield little to no profit for several years, whereas renewed interest in the work could increase its sales years or decades later, sometimes long after the writer's passing. The volume of the final work rarely reflects its quality, or the time spent drafting. Moreover, the quality of the work is very often irrelevant to its commercial success. Artistic or literary works generally reflect the creators' vision transcending space and time. For this reason, judgement on the value of the work is often left to posterity.

6 The image of the intellectual and consequently of the writers has long been associated with their strong independent conscience and their capacity to distance themselves from society's norms. Progressive, independent and original thinking would form the ethos of writers, either stemming from the belief in their intuition or from the strong moral and social compass, characteristic of enlightened individuals. In the United States in particular, where Saroyan was raised and worked for the greatest part of his life, philosophy and literature were greatly influenced by the Romantic Movement, which had forged the image of the romantic genius in contact with nature, moved by emotions and inner sensibilities, whose work is almost solipsist. An important theoretical contribution to the interpretation of this empirical image of the writer can be found in Pierre Bourdieu's field theory, which examines the social relations through the interaction of individuals (called agents) inside social fields formed according to their habitus ${ }^{8}$ and which are largely subordinate to power and class relations. Through the study of the case of the Republic of Letters, a community transcending space and time created in the seventeenth century by literati who shared texts, translations and art $^{9}$, and through the observation that the networks that bring together writers and artists transcend countries and languages and respond to a distinct set of values, Bourdieu reached the conclusion that the literary field is indeed relatively autonomous from the social field. Bourdieu's field theory is the underlying substratum for Dominique Maingueneau's theory on literary discourse analysis that evolves around the core notion of paratopia, which is essential to our analysis of Saroyan's work pertaining to exile and to the trivialization of success and failure.

7 According to Dominique Maingueneau, like every form of discourse, literature is also part of a discursive field, and is thus conditioned by the social context in which it emerges. However, literary discourse transcends common ideas and common language and represents an authority. It is self-constituting, meaning that it "produce[s] texts whose structures must be legitimised by discourse itself ${ }^{10}{ }^{0}$. Maingueneau challenges the romantic image of the writer who is completely separated from society and institutions, arguing that neither the writers nor the works produced could be completely separated from society. Rather they occupy a liminal space on the frontier between the literary field and society. In this condition of in-betweenness, writers are allowed to express themselves without being swallowed up by the society and the values they consider incompatible with their literary identity. In order to conceptualise 
the writer's liminal positioning, which creates the conditions for literature to exist, Maingueneau coined the term paratopia, designating " a paradoxical belonging, which renders possible the statements claiming to exceed the space that they have the function of founding ${ }^{11} "$.

Maingueneau identified several types of paratopia, such as linguistic paratopia: «my language is not my language ", spatial paratopia: "of all exiles: my place is not my place » and paratopia of identity which is associated with dissent and marginality: « my group is not my group ». According to Maingueneau:

The creator thus appears as someone who belongs nowhere and who must build their work around this very flaw. Their statement is uttered through the very impossibility of assigning themselves a real «place». They nourish their work with the radically problematic character of their belonging to the literary field and to society ${ }^{12}$.

Thus, paratopia, i.e., the legitimisation of literary discourse describes a situation of inbetweenness, which is identified with the definition of exile. According to Alexis Nouss, exiled individuals live in a bipolar world. They oscillate between their place of origin and the following stages of their itinerary, "supporting a dynamic of multibelonging ${ }^{13}$ ». The status of exile necessarily implies a transformation of the exiled individuals, who can no longer fully identify neither with the place they leave behind nor with the places where they settle thereafter: «[Exiled individuals] do not cross borders, they are 'border beings that have no border ${ }^{14}$ '». Edward Said in his Representations of the Intellectual also associates exile with a "median state, neither completely at one with the new setting nor fully disencumbered of the old, beset with half-involvements and half-detachments ${ }^{15} \%$. Said's Gramscian definition of intellectuals ascribes them the role of representing values, of bearers of a moral conscience that sets them apart from the rest of society, in the median state evoked above, which can be further aggravated by their own geographical exile and its ideological aspects or by their need to defend the exiled ${ }^{16}$. In short, the intellectual ought to act like an outsider or in favour of the outsider.

There is a connection between exile as a median state and literary creation as social inbetweenness, understood as the creator's distancing from the consensus and the common language in order to formulate a unique discourse. Writers and exiled individuals are borderline, paratopic beings, forced to live either between two or more countries and cultures or between the literary field and the obligations of society. Whereas not every exiled individual is an artist or a writer, yet those among the exiled who decide to take up artistic or literary activities draw from their liminal position, which constitutes both the condition and the product of the statements that are legitimised by this liminal position. Given the fact that exile is a condition for writing, for that reason writing can be particularly beneficial to individuals in a situation of geographical, social and ideological exile, as their liminal or foreign perspective could be legitimised through literary expression or could be transformed into a privilege, allowing them to produce particularly challenging and original work.

Creative exile and paratopia describe a writer's or an artist's capacity to differentiate themselves from society and its conventions in order to assert their distinct literary and artistic voice, vision and identity. The sociologists of art mentioned above (P. Bourdieu and N. Heinich) consider differentiation as a constituent element of any contemporary artistic activity. Heinich's analysis of the vocational aspect of artistic activity, which is influenced by the Romantic notion of singularity, brings forth several 
cases of contemporary artists, whose claims to differentiation foster commercial rejection of their work and postpone success, sometimes until long after their passing:

An ideal artistic work resists the expectations of the general public as much as possible, requiring from its creator to be able to delay for a long time - and sometimes all their life - the moment from which they earn a living from their creation, by practicing a second profession and by reducing their standard of living, possibly by resorting to public subsidies. [...] Great and fast recognition can therefore only reflect poor quality $[. . .]^{17}$.

12 The reasoning behind this argument is that artists cater to their own vision and not to the needs of the masses. Although their work can attract a circle of followers, their innovative perspective is more often a guarantee of commercial failure than of success. $\mathrm{N}$. Heinich argues that singularity is innovative and radical, fostering a great risk of marginalization ${ }^{18}$. Creativity as a manifestation of distinctiveness rarely produces commercially successful work. In that sense, artists are more often prone to fail and not be accepted immediately after the production of the work. Acceptance and success may occur when the work is reconsidered and re-evaluated by future generations; having proven their visionary qualities and withstood the test of time, artists earn a place in posterity as real visionaries. Similarly, failure in posterity seriously questions not only the value of the work but the very core of artistic identity. According to the vocational perception, creators that are criticised in hindsight for their lack of vision and shortsightedness and for base motives that led them to create solely in order to please and coax the public and the critics, are considered to have failed in their mission as artists $^{19}$.

13 It is thus understood that creative exile and paratopia foster conditions for commercial or social failure as they are synonymous with an artist's right to distinctiveness and singularity. The notion of singularity and its incompatibility with the social and commercial aspects of acceptance, success and failure presents several points of affinity with several key characteristics of Transcendentalist philosophy, which was America's response to Romantic subjectivity. Transcendentalism was an American philosophical movement which stressed the importance of self-reliance, subjective intuition and belief in the innate goodness of man as opposed to the corruptive effect of society's structures on individual thinking. Proponents of Transcendentalism would also advocate for the promotion of distinctly local, American themes in literature. The founder of the movement, Ralph Waldo Emerson perceived ideological exile as the only acceptable state of being for every individual, not only for artists and writers.

Transcendentalists argue that society's oppressive structures pose a threat to individual liberties. Based on this premise, it would be reasonable to assume ${ }^{20}$ that Transcendentalism does not perceive exile as banishment but rather as a status people should aspire to in order to be free. According to Emerson, they shouldn't seek conformity and resort to imitation in order to gain acceptance but should trace a path of their own dictated by their intuition, in a very similar manner to the creative exile of artists and writers and to the social exile of Saroyan's characters, the dreamers, who value their own thinking above the opinions of the crowd:

Whoso would be a man must be a nonconformist. He who would gather immortal palms must not be hindered by the name of goodness but must explore if it be goodness. Nothing is at last sacred but the integrity of your own mind. [...] The great man is he who in the midst of the crowd keeps with perfect sweetness the independence of solitude ${ }^{21}$. 

influenced his philosophy of life, allowing him to legitimise his Americanness by defending transcendentalist American values as we will see further on in this article. The importance placed by Transcendentalists on individualism overshadows the importance of social integration and belonging to a social group, transforming geographical exile either into something tolerable or into something irrelevant and insignificant. The 'transcendental ethos' and the 'ethos of the exiled writer' complement one another, as they both question uniformity and preconceptions, providing solace and a raison d'être in a situation of liminality.

eral Transcendentalists such as Emerson also oppose materialistic definitions of success that have become prevalent in American society since the mid-nineteenth century, namely that success can be achieved only through professional or financial soundness. In the introduction of his "Compensation », Emerson rejects the idea that righteous people are not rewarded as they are often poor and failures, whereas sinful people are often promptly rewarded and successful, because success and failure cannot be measured by money, but by people's strength of will and search for the truth, for which they will be compensated according to the Law of Sowing and Reaping - or Law of Compensation as it was named by Emerson. Emerson's theological approach to compensation was based on his observations from sermons he heard as a child. He criticises preachers as «deferring to the base estimate of the market of what constitutes manly success instead of confronting and convicting the world from the truth; announcing the presence of the soul; the omnipotence of the will ${ }^{22}$ ».

In his essay called "Love", where he shares his views on aesthetics, Emerson argues that art and poetry can be successful when they are incomprehensible and astonishing, as only then can they inspire "gleams and visions ${ }^{23}$ " and a need to attain the unattainable:

The statue is then beautiful when it begins to be incomprehensible, when it is passing out of criticism, and can be no longer defined by compass and measuringwand, but demands an active imagination to go with it [...]. And of poetry the success is not attained when it lulls and satisfies but when it astonishes and fires us with new endeavors after the unattainable ${ }^{24}$.

18 Emerson's rejection of market success and failure and the endorsement of values such as individuality and nonconformism by Transcendentalism stress the importance of self-reliance, regardless of the opinions of the crowd. All the above describe a form of ideological exile which is necessary for the expression of creativity and singularity. In the case of artists and authors, their in-betweenness, their moral authority and transcendental vision discussed above, often render the evaluation of their work through traditional or market-oriented definitions of success almost impossible. As suggested both by Said and by Emerson, artists and writers tend to adopt an outsider's viewpoint in order to scrutinise and challenge stereotypes, values, ideas and conventions, suggesting alternative ways of thinking and being, whereas traditional approaches to success are largely based on market needs, which are conditioned by the public's generally accepted tastes, morals, norms and expectations. In this particular context, an artist's path to success might be paved with failure and controversy, reflecting the public's reluctance to accept challenging ideas.

19 The complementary values and characteristics that distinguish the literary and artistic activity (creativity, singularity, in-betweenness) coupled with the intellectual exile 
advocated by Transcendentalism encourage personalised definitions of failure that reflect the artist's singularity and vocation to challenge, inspire and innovate ${ }^{25}$, over social definitions of failure associated with art as a money-making activity. For artists and writers whose work revolves around a vision or bears the characteristics of a mission or a vocation, success couldn't possibly be measured exclusively in terms of profitability or acceptance of the work by the public or by critics; but first and foremost, by evaluating whether the work is aligned to the artist's personal and artistic principles. In the vocational transcendentalist perception of artistic activity, the criteria of failure are strictly personal and defined by the creator, as opposed to the perception of art as a professional activity, according to which the criteria are socially determined and are aligned to the rules of the market, reflecting the attractiveness of the artistic work as a commodity. The perception of art as a professional activity requires immediate monetary or critical evaluation of the work, which might be considered untimely, illegitimate or irrelevant from the creator's perspective.

The values and characteristics of creation and the transcendentalist approach discussed above were particularly relevant to Saroyan, who took writing as a means to legitimise his exile by resemantising it according to all-American Transcendentalist values. His literary identity i.e., his creative exile complemented and legitimised his double identity as an Armenian-American i.e., his geographical exile. Therefore, his exile would no longer be an unbearable plight but a privileged condition which would allow his creative paratopia and his sharing between his ancient Armenian roots and the multi-ethnic mosaic of America to mingle, forming a powerful tool of analysis of the human condition, which would define his mission as a writer. His frequently troubled relations with critics and his very personal, transcendentalist approach to failure associated with the vocational aspect of his work were reflected not only in the themes, techniques and opinions conveyed in his prose and plays but also in his overall posture, all of which are studied below.

\section{Failure, Transcendentalism and Theatricalism}

21 For Saroyan, writing was a way of negotiating his double culture and countering the stereotypes of Armenians, cultivated by the racist and nativist ideologies prevalent in the nineteenth and early twentieth century in the US. It was also a means of escape from his social condition and from the repetitiveness of manual work which would have been his bread and butter, like any poor immigrant, had he not penetrated into the world of mental labour. "I took to writing at an early age to escape from meaninglessness, uselessness, unimportance, insignificance, poverty, enslavement, ill health, despair, madness, and all manner of other unattractive, natural and inevitable things ${ }^{26} »$. Writing was the most accessible type of artistic expression especially since the broader impoverishment of American society during the Great Depression. "In order to write all a man needs is paper and a pencil ${ }^{27}$ ", Saroyan would often say.

Saroyan's authorial persona was built around a deeply ingrained belief that regardless of the commercial failure of his novels and plays and the staunch criticism he very often received, his work was always legitimate as it stemmed from a transcendental ethos, namely the need to capture the essence of humanity reflected in the founding values of the American nation at a time when these values had been replaced by the pursuit of money and success and had been submerged under ideological warfare. For 
that reason, he would refuse to comply with political ideologies, or follow the literary and theatrical tendencies of his time. The American novelist and critic Mary McCarthy summarised Saroyan's posture as follows:

He still retains his innocence [...] that is, he has had to fight off Ideas, Movements, Sex, and Commercialism. He has stayed out of the literary rackets - the Hollywood racket, the New York cocktail-party racket, and the Stalinist racket. [...] What is more important, the well of inspiration, located somewhere in his early adolescence, has never run $\mathrm{dry}^{28}$.

Saroyan's inalienable right to failure against the liberal society's standards and expectations of success was his own way of claiming his right to freedom and individuality and his connection to Transcendentalist values, which he considered the only true American values, based on self-reliance and self-trust. Since Transcendentalism was the first properly American philosophical movement, Saroyan's arduous defence of Transcendentalist values which had been destroyed by industrial society and by capitalism allowed him to legitimise his American identity on the basis of his adherence to essentially American principles instead of his origins.

On multiple occasions, Saroyan would express his admiration of Walt Whitman, whom he described as quintessentially American, the pioneer of the unschooled and the poet of the common men of America, who voiced the troubles of everyday people and who inspired Saroyan's decision to take up writing at an early age ${ }^{29}$. Regardless of his reputation in posterity, Whitman's lack of academic credentials, unsophisticated voice and vision made him quite unpopular during his lifetime. Whitman's transcendentalist approach is obvious in the "Song of Myself", which revolves around the themes of total belief in personal intuition and of self-exploration. Whitman's paratopic position gave him the freedom to express revolutionary or unpopular ideas through his poetry, such as the relativization of failure and success and his praise of the failed in the eighteenth section of "Song of Myself " which aimed at reconciling the victorious North with the defeated South after the Civil $\mathrm{War}^{30}$. His use of free verse, a novelty that made him a pioneer of American poetry, was not readily accepted by the critics of his time. Whitman's fearless and independent thinking, and his indifference towards typical definitions of success had greatly influenced Saroyan's ethos. Saroyan's return to grassroots literary models, anchored in popular culture and thus profoundly American but considered very old-fashioned at his time, allowed him not only to legitimise his frequently unpopular positions and his notoriously unsophisticated aesthetics, but also to assert himself, an immigrant, as a successor of great American writers, such as Mark Twain and Walt Whitman.

A prolific writer, Saroyan wrote several novels, hundreds of short stories and around forty plays, most of which have never been staged or even published. Although considered particularly successful in the mid-thirties up until the early forties, as his early short stories and his first three plays My Heart's in the Highlands (1939), The Time of your Life (1939) and Love's Old Sweet Song (1941) captured the difficulties and shattered dreams of the common man in the Depression era, Saroyan's success would recede by the end of the Second World War. Critics would very often shun the anti-military spirit and apparent neutrality of his novels and plays, which went against the tide of the anticommunist and patriotic sentiment of that time and became increasingly sceptical towards Saroyan's resistance to the literary and theatrical canon and trends. A feature on Saroyan, published on November $18^{\text {th }}, 1940$ in Life Magazine, titled "The Great Saroyan: Fresno's elfish Armenian boy has the time of his life becoming a famous 
playwright ${ }^{31}$ " startles the reader with its equally laudatory and somehow condescending tone. Saroyan is depicted as an oddity in the entertainment world, a talented but self-centred and rustic eccentric with a boyish demeanour that never edits or keeps copies of his work and writes in new characters or makes last-minute changes in his plays. The article concludes with an anecdote bearing evidence to Saroyan's selfappraisal as the greatest writer in the world, which is in striking contrast to the critics' opinions mentioned in the above feature.

Saroyan took to playwriting as a means of experimenting with different genres, as experimentation constituted an essential aspect of his creative process ${ }^{32}$. He adhered to the principle that writers shouldn't specialise in a specific genre or form but should explore the possibilities offered by different genres and forms, preferably simultaneously. This might have been one of the primary reasons why Saroyan aimed at adapting his stories to several genres and forms and was adamant about reworking them himself, probably as an exercise in point-of-view and tailoring the plot and its devices to the capacities of each medium. During his career he adapted novels for the theatre and for the screen and vice-versa, believing that each medium had a specific potentiality that could help him propagate his beliefs and his vision. Given the fact that he had acknowledged the didactic aspect of his work, we are led to believe that he intended to reach different audiences and amplify the message contained in his work through the diversification of media and forms and his transgression of genres.

Theatre is crafted to engage the emotions of viewers in different ways compared to reading a novel. In theatre, emotions and human behaviours are not merely described, but witnessed and experienced by the viewers through the actors' movements, facial expressions, interactions with one another, with their surroundings (scenery, audio) and sometimes with the audience. For that reason, theatre as a collaborative form of performance, fosters a particularly high degree of intimacy which activates empathy ${ }^{33}$, allowing for the viewers to relate to what is represented on the scene. Our empathetic resonance is activated through the perception of another's state, primarily visually through imitation ${ }^{34}$ which is one of the key aspects of acting. Saroyan's representation of vagrants and people on the brink of desperation that are generally associated with failure but who also manage to find reasons to smile, dream and love on stage urges the viewers to empathise with these characters who shouldn't be reduced to their failures and to their marginal status but should be considered under a different light. Given the difficulties experienced during the Great Depression where some of the stories take place, Saroyan argues that there can be humour and joy in failure as the protagonists pick themselves up playfully and with resilience after each calamity or are happy to wake up to see another day. The moral lesson conveyed to the viewers is that life has to be lived to its fullest, with optimism and resilience or indifference to failure, especially when failure is attributed to presumed lack of efficiency and incapacity to adapt to the liberal system. As an orphan belonging to an ethnic group that had barely survived annihilation and had suffered centuries-old oppression by the Ottomans, Saroyan knew all too well the inevitability of death and the deprivation of liberty. For that reason his works incite viewers to celebrate the wonder of life and treat lack of money or lack of success to which people usually attach great importance and which form the basis for the social evaluation of individuals, as minor inconveniences.

At a time when realism would prevail in American theatre with major figures such as Eugene O'Neill, a Nobel prize and multiple Pulitzer laureate for Drama, Robert E. 
Sherwood also a multiple Pulitzer laureate for Drama, but also Rachel Crothers, Elmer Rice, Philip Barry and Susan Claspell to name a few, Saroyan would stand behind the non-realistic mode of his plays, and consider their commercial success or failure as irrelevant to the search of true being and to the infinite possibilities to live one's life ${ }^{35}$, the aims of art and drama which, according to Saroyan, transcend time, space and specific social conditions. Saroyan would resort to constant experimentation, namely the exploration of different types of performance (vaudeville, pantomime, opera, ballet) and great stylistic variety, introducing elements of histrionic reality in his plays. This type of reality is specific to theatrical creation and distinct from the illusion of offstage reality of realistic theatre ${ }^{36}$. Although Saroyan's unrealistic approach and theatricality are reminiscent of Brechtian theatre, as they achieve a distancing effect and cultivate the critical spirit of the viewers, Saroyan's intentions are different from Brecht's. Saroyan's theatre generally lacks the social and Marxist dimension of Brecht's theatre, focusing instead on the inner revolution of the individual and the necessity for empowerment from within. The non-realistic approach and the strong elements of theatricalism in Saroyan's plays serve as a means of achieving transcendence, as they celebrate the wonder of being alive by inciting the viewers to leave behind oppression, fear of failure and reality where life is but half-lived, offering in exchange a peek inside the realm of dreams represented by the fantasy of theatre where life can always be lived to the fullest. Metatheatre as an expression of histrionic reality is also present in Saroyan's work. In " The Playgoers ", Saroyan's characters discuss theatricalism as they act on stage:

Wife: Did you just say the better the actors the less you like it?

Husband: Precisely.

Wife: If they're bad, do you like it?

Husband: Yes, I enjoy acting that's bad. I think acting ought to be bad-lousy, in

fact.

Wife: That's strange? Why?

Husband: So everybody can know that it is acting. [...]

Wife: You don't want acting to be real?

Husband: Heaven forfend, as an actor might say. Acting that tries to be real is an insult. The reality of the real, which happens in the play that lasts a lifetime, is the only reality of that kind I am willing to tolerate ${ }^{37}$.

Stylistic reinvention and experimentation, unpredictability and lack of structure would hinder his plays from reaching a bigger audience as they defy the notion of a recipe for success and the expectations of the public, which very often form the basis of what is considered a commercial success. Furthermore, the aforementioned elements of surprise would make the classification of his plays, both in terms of theatrical movements and in terms of forms and genres, impossible. Saroyan's subversive attitude towards the structures of power in the literary and theatrical field, such as critics, editors and guilds is visible in the main body of his work but also in the paratext. In the introduction to his play Love's Old Sweet Song, Saroyan replies to criticism about lack of structure and insensibility to social issues and theatrical conventions. He argues that even though critics reproach him for his lack of style and structure, style and structure are indeed present, but that they are not what the critics would expect from him. He defends the transcendental values of his work and the theatricalism of his art, which is meant to sweep the audience away from what is happening outside the theatre with the hope of transforming reality itself, as against the critics' accusations of mindlessness. The abundance of Saroyan's similar responses to critics underlines the importance of 
personal intuition, as opposed to society's expectations, but also the primacy of the motivations and personal considerations behind one's work, over the reception of the work by the public or the critics, which are core elements of transcendental philosophy:

Since the theatre is not an adult continuation school, those who come to the theatre must be entertained before they are instructed ${ }^{38}$. [...] The difference between my thinking, it would appear, and the thinking of others is that mine operates from beginnings long ago and not from headlines and news in today's paper ${ }^{39}$.

Derek Attridge, in his essay about experimental art, argues that the success of an experimental art project can only be evaluated with hindsight ${ }^{40}$. During the build-up and upon completion of the work, artists cannot foresee the effect of the experimentation on the artistic landscape. Deviations from well-trodden paths involve a considerable amount of risk, and the chances of the experimentations or innovations being readily accepted are quite slim. Jacques Derrida argued that the notion of transgression, which forms the core of the concept of innovation, is incompatible with acceptance:

At the moment where it erupts, the inaugural invention ought to overflow, overlook, transgress, negate. [...] It ought to overstep the space in which the status itself takes on its meaning and legitimacy - in short, the whole environment of reception that by definition ought never to be ready to welcome an authentic innovation ${ }^{41}$.

31 By choosing the path of experimentation and individuality, Saroyan accepted the risks entailed. His stance revealed that he made a clear distinction between personal failure as a result of having deviated from his principles, the only type of failure he would acknowledge as such; and the social aspects of failure, such as lack of acceptance or praise by those who are exterior to the creative process. According to Saroyan's personal philosophy, a work can indeed be labelled a success as long as the motives and ideas behind the work are unadulterated and the aims of the creator are met.

Saroyan's reaction after receiving the Pulitzer Prize for his play The Time of your Life, stating that this play was " "no more great or good" from anything else he had written $^{42}$ ", is consistent with his philosophy of indifference towards external definitions of success and failure. Saroyan's statements about the Pulitzer are in accordance with the ideological and social alienation and exile conditioned by his paratopia. In his statements, Saroyan rejected the prize and voiced his objection to any form of criticism and patronizing of the arts, expressing his belief that art cannot exist without absolute freedom and should not be subject to the power relations of the financial system ${ }^{43}$. Even though Saroyan's writing is devoid of political bias towards a specific political ideology, it is nevertheless far from being apolitical. In his introduction to the 1940 edition of his first three plays, Saroyan stated that: « Art and politics must move closer together. Reflection and action must be equally valid in good men if history is not to take one course and art another. [...] Political systems, however [...] are worthless when they can survive only at the cost of the actual lives of the people they claim to protect ${ }^{44} »$. 


\section{Failure, failures, dreamers: Saroyan and the liberal American identity}

33 From the very beginning of his career until his passing, Saroyan would stress the importance of dreaming as a way of imagining another way to live and as a form of resistance to the pragmatism of society. His experiments with histrionic reality in his plays, discussed above, are also proof of his need to explore and imagine the possibilities of alternative ways of being. The dipole of failure and success featuring in his plays would serve as a tool to unmask the flaws of existing political systems. His constant staging of characters that are considered failures by society's standards is aligned on his conviction that life in society is almost always incompatible with the notions of freedom and equality and that oppression is inevitable. One of his most famous plays My heart is in the Highlands, dedicated to the "Pure in heart, the poet in the world", evolves around the dipole of failure and success and stages two main characters, artists and dreamers that are considered failures. The man whose Heart is in the Highlands, the anonymous archetype of the vagabond alluding to Saroyan himself, the exiled Armenian that longs for the Armenian Highlands, or to any exiled individual, finds solace in the house of a poet that strives to make ends meet by his writing. The scene where the poet's son tries to persuade the local grocer to give him food on credit opposes the dreamy disposition of the main character to the pragmatist thinking of the grocer, as the latter sees through the boy's clever mannerisms: « This ain't China. You got to go out and make a living in this country. Everybody's got to work in America ${ }^{45}$ ”.

As the US evolved into a heavily industrialised, liberal capitalist society in the course of a century between the 1850's to the 1950's, an evolution that both Whitman and Saroyan experienced, though at different stages, the notions of success and failure underwent resemantisation, reflecting the rapid transformations of the society and its core values. Scott A. Sandage in his cultural account of failure in the $19^{\text {th }}$ and the $20^{\text {th }}$ century argues that, as trading and business became the national religion of the US in the course of the $19^{\text {th }}$ century, the idea of virtue and vice as well as the religious concept of predestination was transposed in social life. Thus, the idea of people who had experienced failure at some point in their lives were replaced by the idea that people could be failures. Lack of vigour, which was at that time synonymous to virtue, paired with a poor entrepreneurial mind-set were considered as traits of a defective character. As Sandage points out « the only identity deemed legitimate in America is a capitalist identity ${ }^{46} »$.

Saroyan grew up in a social context where the foreign-born were americanised through the accumulation of material wealth. Being American in the $20^{\text {th }}$ century was less associated with ethnic belonging (apart from Native Americans and Blacks who were still indistinctively othered) and more with the capacity of individuals to consume, trade and conform regardless of their origins ${ }^{47}$. According to Sandage, the Great Depression was a period of « unmasking ${ }^{48}$ » of the illusions of universal success, which allowed for previously marginalised individuals like Saroyan to succeed while writing about the failures that everyone had experienced but no one had dared to express up until then. However, by the end of the 1930's and as WWII patriotism exploded, the allAmerican virtue of financial enterprise resurfaced, stronger than ever and rivalling the communist agenda. Saroyan's insistence with dreamers and failures up to his death coupled with his antimilitarism, led to his disappearance from the literary world and 
the theatre. However, as he would often point out, the lack of interest from publishers didn't deter him from writing plays up to his death.

The collection of short plays titled Making money and nineteen other very short plays published in 1969 features, among others, a short play called «Waiting Room ». In this play, Saroyan presents Tidy Man, an average individual and Untidy man, a nervous one, both sitting in the waiting room of a doctor's office. Tidy Man grows concerned by Untidy Man's erratic behaviour and proceeds to criticise his inability to work like everybody else. "If you are good at sitting around, you could get a job that calls for sitting around-like a desk clerk ${ }^{49} »$. Towards the end of the play it is revealed that Untidy Man has sustained injuries in war and has been suffering from PTSD ever since. In another play from this series called "The Conversationalists " Saroyan stages a couple discussing everyday life and money. The wife argues that earning a lot of money is proof of cleverness and that money-making would allow their children to study at Harvard and become successful; to which the husband, an English language teacher that doesn't earn as much as a businessman, responds that cleverness is irrelevant to money-making and success and that their children must be free to decide whether they want to study at Harvard or not at all. Their argument, opposing the materialist wife to the idealist husband ends with the husband's complaint about the wife's choice of subjects. Saroyan drops the curtain with the wife's meaningful phrase: «You think too much $^{50} »$. This short play opposing the dreamer preoccupied with intellectual and existential questions and who is deemed a failure, to the pragmatist who only translates success in terms of material wealth and social conformity is quite representative of Saroyan's position on this subject. The majority of his plays and novels oppose the dominant way of thinking that crushes the individual's aspirations, to what Saroyan considered a more meaningful way of thinking and an alternative way of being, that liberates the individual from the shackles of socially acceptable notions of success and failure, allowing them to flourish as their own true selves.

Saroyan's posture is a typical example of a writer's fearless approach to success and failure. By emphasising the paratopic position of artists and writers and proudly displaying his outsider status, Saroyan developed a strategy of resistance against America's rejection and fear of failure, thus challenging the American Dream as a liberal ethos that capitalises on (over)achievement. Saroyan's Transcendentalist ethos dictates that art that stems from an inner need and resists the intimidating possibility of rejection by the outside world can indeed be successful and a very satisfying and educational process both for the creator but also for the public. Finally, Saroyan's work encourages the public to focus on their own motivations and principles and disregard external definitions of success and failure as global change can only be achieved through individual change, through the discovery of one's true self and emancipation from oppression. 


\section{BIBLIOGRAPHY}

ATTRIDGE, Derek, « What Do We Mean by Experimental Art? », in Angles: New Perspectives on the Anglophone World, [en ligne]. URL: https://doi.org/10.4000/angles.962 [Site consulté le 20/08/20].

BALAKIAN, Nona, The World of William Saroyan, London, Bucknell University Press, 1998.

BLAIR, Rhonda, « Notes on Empathy, Cognitive Neuroscience, and Theatre/Education », in p-e-r-fo-r-m-a-n-c-e, [en ligne], vol. 2, n 1-2, 2015. URL : http://www.p-e-r-f-o-r-m-a-n-c-e.org/? $\mathrm{p}=1101$ [Site consulté le 23/02/21].

BOTS, Hans, and WAQUET, Françoise, La République des Lettres, Paris \& Bruxelles, Belin-De Boeck, coll. «Europe et Histoire », 1997.

BOURDIEU, Pierre, « Habitus » in Habitus: A Sense of Place, HILLIER, Jean, and ROOKSBY, Emma [eds.], Aldersho, Ashgate, 2002.

CALONE, David Stephen, My real work is being, foreword by KOUYMJIAN, Dikran, Chapel Hill \& London, The University of North Carolina Press, 1983.

COX, Robert Henry, and SCHILTHUIS, Albert, «Hegemony and Counterhegemony» in Encyclopedia of Globalization, RITZER, George [ed.], Boston, Wiley Blackwell, 2012, p. 923-927.

DERRIDA, Jacques, «Psyche: Invention of the Other » in Psyche: Inventions of the Other, KAMUF, Peggy, and ROTTENBERG, Elizabeth [eds.], Stanford, Stanford University Press, 2007.

EMERSON, Ralph Waldo, Essays: First Series, Boston, Houghton Mifflin and Company, 1883.

HASLAM, Gerald W., « William Saroyan » in A Literary History of the American West, GOLDEN, Taylor J. , WESTBROOK, Max, ETULAIN, Richard W., and LYON, Thomas J. [eds.], Fort Worth, TCU Press, 1987.

HEINICH, Nathalie, «Façons d'être' écrivain. L'identité professionnelle en régime de singularité ", in Revue française de sociologie, $n^{\circ}$ 36, vol. 3, 1995.

HEINICH, Nathalie, « Personnes, objets, situations : trois variations sociologiques sur la nature juridique des phénomènes artistiques », in Profils de la création, [en ligne], LIBOIS, Boris, STROWEL, Alain [eds.], Bruxelles, Presses de l'Université Saint-Louis, 1997. URL : http:// books.openedition.org/pusl/12438 [Site consulté le 16/03/21].

HEINICH, Nathalie, «L'art en régime de singularité : Quelques caractéristiques sociologiques de 1 'art contemporain ", in Art et société : Recherches récentes et regards croisés, Brésil/France, [en ligne], QUEMIN, Alain, and VILLAS BÔAS, Claucia [eds.], Marseille, OpenEdition Press, 2016. URL : http:// books.openedition.org/oep/530 [Site consulté le 16/03/21].

HELLMAN, Geoffrey T., « Great Saroyan », Close-up, Life, 18 November 1940.

HOVANESSIAN, Martine, Le Lien communautaire. Trois générations d'Arméniens, Paris, Armand Colin, 1992.

KIM, Ki-Ae, « Theatricalism in the plays of William Saroyan », Doctoral thesis in Drama and Theatre supervised by Professor CAROLL, W. Denis, University of Hawaii, 1990.

KOUYMJIAN, Dickran, « Whitman and Saroyan: Singing the Song of America», in Walt Whitman Quarterly Review, n 10, Summer 1992. 
LEE, Lawrence, and GIFFORD, Barry, Saroyan: A Biography, Berkeley, University of California Press, 1998.

MAINGUENEAU, Dominique, Le contexte de l'œuvre littéraire, Paris, Dunod, 1993.

MAINGUENEAU, Dominique, «Literature and discourse analysis », in Acta Linguistica Hafniensia, [en ligne], 42(sup1), 2010, p. 147-158. URL : https://doi.org/10.1080/03740463.2010.482325 [Site consulté le 20/08/20].

NOUSS, Alexis, La condition de l'exilé, Paris, Éditions de la Maison des Sciences de l'Homme, coll. «Interventions », 2015.

ROSENBERG, Emily S., « Le modèle américain de la consommation de masse », in Cahiers d'histoire. Revue d'histoire critique, [en ligne], $\mathrm{n}^{\circ}$ 108, 2009. URL : http://journals.openedition.org/chrhc/1809 [Site consulté le 23/09/20].

SAID, Edward W., Representations of the Intellectual: The 1993 Reid Lectures, New York, Vintage Books, 1996.

SANDAGE, Scott A., Born Losers: A history of failure in America, Cambridge, Massachussetts and London, Harvard University Press, 2006.

SAROYAN, William, Three plays, New York, Harcourt, Brace and Co., 1940.

SAROYAN, William, Love's Old Sweet Song, New York \& Los Angeles, Samuel French, 1941.

SAROYAN, William, My Heart's in the Highlands, New York, Samuel French, 1941.

SAROYAN, William, The Bicycle Rider in Beverly Hills, New York, C. Scribner's sons, 1952.

SAROYAN, William, Here comes, there goes, you know who, New York, Simon and Schuster, 1961.

SAROYAN, William, I Used to Believe I Had Forever, Now I'm Not So Sure, New York, Cowles, 1968.

SAROYAN, William, The Dogs, or The Paris Comedy and Two Other Plays: Chris Sick, or Happy New Year Anyway; Making Money, and Nineteen Other Very Short Plays, New York, Phaedra, Inc. Publishers, 1969.

SAROYAN, William, Sons come and go, mothers hang in forever, New York, McGraw-Hill, 1976.

WHITMAN, Walt, « Song of Myself, 18 », in Leaves of Grass: With a complete commentary, FOLSOM, Ed, and MERRILL, Christopher [eds.], Iowa City, University of Iowa Press, 2016.

\section{NOTES}

1. Walt, Whitman, «Song of Myself, 18 », Leaves of Grass: With a complete commentary, Ed Folsom, Christopher Merrill [eds.], Iowa City, University of Iowa Press, 2016, p. 60.

2. William, Saroyan, I Used to Believe I Had Forever, Now I'm Not So Sure, New York, Cowles, 1968, p. 96.

3. Nona, Balakian, The World of William Saroyan, London, Bucknell University Press, 1998, p. 186.

4. William, Saroyan, Sons come and go, mothers hang in forever, New York, McGraw-Hill, 1976, p. 20.

5. Martine, Hovanessian, Le Lien communautaire. Trois générations d'Arméniens, Paris, Armand Colin, 1992, p. 297. Alexis, Nouss, La condition de l'exilé, Paris, Éditions de la Maison des Sciences de l'Homme, coll. «Interventions », 2015, p. 29.

6. Robert Henry, Cox, and Albert, Schilthuis, "Hegemony and Counterhegemony", in Encyclopedia of Globalization, George Ritzer [ed.], Boston, Wiley Blackwell, 2012, p. 923. 
7. Nathalie, Heinich, «Façons d'être' écrivain. L'identité professionnelle en régime de singularité ", in Revue française de sociologie, $\mathrm{n}^{\circ}$ 36, vol. 3, 1995, p. 505.

8. "[...] system of dispositions, that is of permanent manners of being, seeing, acting and thinking, or a system of long-lasting (rather than permanent) schemes or schemata or structures of perception, conception, and action. » Pierre, Bourdieu, « Habitus », in Habitus: A Sense of Place, Jean, Hillier and Emma, Rooksby [eds.], Aldersho, Ashgate, 2002, p. 27-28.

9. Hans, Bots, and Françoise, Waquet, La République des Lettres, Paris \& Bruxelles, Belin-De Boeck, coll. «Europe et Histoire », 1997.

10. Dominique, Maingueneau, «Literature and discourse analysis», in Acta Linguistica Hafniensia, [en ligne], 42(sup.1), 2010, p. 147-158. URL: doi:10.1080/03740463.2010.482325 [Site consulté le $6 / 08 / 20]$

11. «[...] désigne une appartenance paradoxale, qui rend possibles des énonciations prétendant excéder l'espace qu'elles ont pour fonction de fonder.» Dominique, Maingueneau, Le Contexte de l'œuvre littéraire, Paris, Dunod, 1993, p. 28.

12. "Le créateur apparaît ainsi comme quelqu'un qui n'a pas lieu d'être (aux deux sens de la locution) et qui doit construire le territoire de son œuvre à travers cette faille même. Son énonciation se constitue à travers l'impossibilité même de s'assigner une véritable "place». Il nourrit son œuvre du caractère radicalement problématique de sa propre appartenance au champ littéraire et à la société. » Ibid., p. 29.

13. Alexis, Nouss, op. cit., p. 29.

14. Ibid., p. 11.

15. Edward, W. Said, Representations of the Intellectual: The 1993 Reid Lectures, New York, Vintage Books, 1996, p. 49.

16. «[...] the intellectual is an individual with a specific public role in society that cannot be reduced simply to being a faceless professional, a competent member of a class just going about her/his business [...] an individual endowed with a faculty for representing, embodying, articulating a message, a view, an attitude, philosophy or opinion to, as well as for, a public. [...] Someone whose place it is publicly to raise embarrassing questions, to confront orthodoxy and dogma (rather than to produce them), to be someone who cannot easily be co-opted by governments or corporations, and whose raison d'être is to represent all those people and issues that are routinely forgotten or swept under the rug. »Ibid., p. 11.

17. "L'œuvre idéale est celle qui fait autant que possible obstacle aux attentes du grand public, exigeant de son auteur qu'il soit capable de différer longtemps - et parfois toute sa vie - le moment de vivre de son art, en pratiquant un second métier, en réduisant son train de vie au plus juste, éventuellement en recourant aux subventions publiques. [...] Une reconnaissance large et à court terme ne peut donc que signifier une qualité médiocre [...]». Nathalie, Heinich, "L'Art en régime de singularité : Quelques caractéristiques sociologiques de l'art contemporain ", in Art et société : Recherches récentes et regards croisés, Brésil/France, [en ligne], Alain, Quemin, and Glaucia, Villas Bôas [eds.], Marseille, OpenEdition Press, 2016. URL : http://books.openedition.org/oep/ 530 [Site consulté le 16/03/2021].

18. «La reconnaissance du singulier dans la modernité repose sur son caractère novateur, qui garantit la rupture avec les traditions antérieures : rupture qui risque de le condamner à la marginalité, sauf à être considérée comme point de départ de mouvements ultérieurs, pivot autour duquel la tradition s'annule pour laisser place à ce qui deviendra une nouvelle tradition ». Ibid.

19. Nathalie, Heinich, «Personnes, objets, situations : trois variations sociologiques sur la nature juridique des phénomènes artistiques ", in Profils de la création, [en ligne], Boris, Libois, and Alain Strowel [eds.], Bruxelles, Presses de l'Université Saint-Louis, 1997. URL : http:// books.openedition.org/pusl/12438 [Site consulté le 16/03/2021]. 
20. We would like to stress the importance of polyphony inside the movement. Contradiction was one of the key features of Transcendentalism, as Transcendentalists valued individualism above the idea of adhering to a doctrine. For that reason, they had the liberty to follow their own path, contradict themselves or be opposed to the ideas of other fellow Transcendentalists. "Speak what you think now in hard words, and tomorrow speak what tomorrow thinks in hard words again, though it contradicts everything you said today. - 'Ah, so you shall be sure to be misunderstood'. - Is it so bad, then, to be misunderstood? Pythagoras was misunderstood, and Socrates, and Jesus, and Luther, and Copernicus, and Galileo, and Newton, and every pure and wise spirit that ever took flesh. To be great is to be misunderstood. » Ralph Waldo, Emerson, Essays: First Series, Boston, Houghton Mifflin and Company, 1883, p. 52.

21. Ibid., p. $46-47$ and p. 49.

22. Ibid., p. 80-81.

23. Ibid., p. 145.

24. Ibid., p. 145.

25. Defined by Heinich as «régime vocationnel», it describes artistic creation as an activity emanating from an artist's need to create as opposed to « régime professionnel » which describes writing as a profession, a money-making occupation. Nathalie, Heinich, op. cit.

26. William, Saroyan, Here comes, there goes, you know who, New York, Simon and Schuster, 1961, p. 2.

27. William, Saroyan, The Bicycle Rider in Beverly Hills, New York, C. Scribner's sons, 1952, p. 87.

28. Gerald, W. Haslam, «William Saroyan" in A Literary History of the American West, Taylor, J. Golden, Max, Westbrook, Richard, W. Etulain, and Thomas, J. Lyon [eds.], Fort Worth, TCU Press, 1987, p. 473.

29. Dickran, Kouymjian, «Whitman and Saroyan: Singing the Song of America» in Walt Whitman Quarterly Review, $\mathrm{n}^{\circ}$ 10, Summer 1992, p. 16-17.

30. Walt, Whitman, Leaves of Grass, op. cit., p. 61.

31. Geoffrey, T. Hellman, « Great Saroyan », Close-up, Life, 18 November 1940, p. 102.

32. Nona, Balakian, op. cit., p. 30.

33. Rhonda, Blair, "Notes on Empathy, Cognitive Neuroscience, and Theatre/ Education ", in p-e-r-f-o-r-m-a-n-c-e, [en ligne], vol. 2, no 1-2, 2015. URL : http://www.pe-r-f-o-r-m-a-n-c-e.org/?p=1101 [Site consulté le 13/02/21].

34. Ibid.

35. Saroyan's stance to art and life is epitomised in his phrase « My real work is being » which became the title of a posthumous critical volume on his work: David Stephen, Calone, My real work is being, foreword by Dikran Kouymjian, Chapel Hill \& London, The University of North Carolina Press, 1983.

36. Ki-Ae, Kim, "Theatricalism in the plays of William Saroyan », Doctoral thesis in Drama and Theatre supervised by Professor W. Denis Caroll, University of Hawaii, 1990, p. 9.

37. William, Saroyan, The Dogs, or The Paris Comedy and Two Other Plays: Chris Sick, or Happy New Year Anyway; Making Money, and Nineteen Other Very Short Plays, New York, Phaedra, Inc. Publishers, 1969. p. 80.

38. William, Saroyan, Love's Old Sweet Song, New York \& Los Angeles, Samuel French, 1941, p. xiiixiv.

39. Ibid., p. xvi.

40. Derek, Attridge, «What Do We Mean by Experimental Art? », in Angles: New Perspectives on the Anglophone World, [en ligne]. URL: https://doi.org/10.4000/angles.962 [Site consulté le 20/08/20]. 
41. Jacques, Derrida, «Psyche: Invention of the Other " in Psyche: Inventions of the Other, Peggy, Kamuf, and Elizabeth Rottenberg [eds.], Stanford, Stanford University Press, 2007, p. 21-22.

42. «William Saroyan ", in Encyclopedia Britannica, [en ligne]. URL : https://www.britannica.com/ biography/William-Saroyan [Site consulté le 20/08/20].

43. " Art must be democratic, but at the same time it must be both proud and aloof. [...] It must not be taken either by praise or criticism. Wealth, I am sure, cannot patronize art, and the strange impulse of wealth to seek to do so is, I believe, a curious example of noble bad taste... A poverty-stricken nation with a great art is a greater nation than a wealthy nation with a povertystricken art. " Lawrence, Lee, and Barry, Gifford, Saroyan: A Biography, Berkeley, University of California Press, 1998, p. 17-18.

44. William, Saroyan, Three plays, New York, Harcourt, Brace and Co., 1940, p. 3-4.

45. William, Saroyan, My Heart's in the Highlands, New York, Samuel French, 1941, p. 17.

46. Scott, A. Sandage, Born Losers: A history of failure in America, Cambridge, Massachussetts and London, Harvard University Press, 2006, p. 5.

47. Emily, S. Rosenberg, "Le modèle américain de la consommation de masse ", in Cahiers d'histoire. Revue d'histoire critique, [en ligne], $\mathrm{n}^{\circ}$ 108, 2009. URL : http://journals.openedition.org/ chrhc/1809 [Site consulté le 23/09/20].

48. "The Great Depression was a great unmasking that many found unbearable." Scott, A. Sandage, Born Losers, op. cit., p. 262.

49. William, Saroyan, The Dogs, or The Paris Comedy, op. cit., p. 83.

50. William Saroyan, Ibid., p. 77.

\section{ABSTRACTS}

This article discusses the authorial persona of American novelist and playwright William Saroyan. It is argued that his approach to failure was an essential element of his ethos and a means of endorsing his role and his social status as a writer, reflecting his disapproval of utilitarianism and conventional definitions of success, equated with wealth and celebrity.

Cet article traite de la construction de l'identité d'auteur de William Saroyan, auteur de nouvelles et dramaturge. Il y est soutenu que l'échec était un élément essentiel de son ethos et un moyen d'endosser son rôle et son statut social d'écrivain, reflétant sa désapprobation de l'utilitarisme et des définitions conventionnelles du succès associées à la richesse et à la célébrité.

\section{INDEX}

Keywords: Saroyan (William), theatre, United States, capitalism, liberalism, ethics

Mots-clés: Saroyan (William), théâtre, États-Unis, capitalisme, libéralisme, éthique

\section{AUTHOR}

\section{CHARIKLEIA MAGDALINI KEFALIDOU}

$\mathrm{PhD}$ in Comparative Literature, Sorbonne University. 